\title{
MANAGEMENT STRATEGIES FOR ACHIEVING ENERGY EFFICIENT AND SUSTAINABLE TRANSPORTATION SYSTEM
}

\author{
Christina Nikolova \\ University of National and World Economy, Sofia, Bulgaria
}

\section{(C) MESTE NGO}

JEL category: Q01, Q4, Q56, R41

\begin{abstract}
This paper aim is to explore the indicators and measures toward sustainable transportation system, with particular emphasis on the energy consumption and trends which prevent the achievement of policy objectives of reconciling the economic interests of the transport sector with energy constraints. Several arguments substantiated by empirical evidence from EU countries are put forward to demonstrate that current megatrends in transport are at odds with a sustainable development and lead to high social costs. A variety of policy strategies is discussed to improve the current threatening situation.

The various paragraphs of this paper concentrate on the real problems which energy efficiency of transport present to policy-makers and assess the contribution that the analysis can make to handling more effectively recpective considerations in transport decision making. Previously, transport energy consumption concerns have been mainly restricted to local factors but recent concerns over the big dependence of the whole EU economy on the fossil fuels and of pollution-induced diseases have given importance to regional, national and global implications.

The paper is to provide a general background against which the new research may be set. It does not aim either to be comprehensive in its treatment of all possible management strategies in transport or to provide answers of the questions that it or its paragraphs raise. It is hoped, however, that it may flag some of the key issues where uncertainty remains and where subsequent research could prove beneficial.
\end{abstract}

Keywords: energy efficiency; sustainable transport; management strategies

\section{INTRODUCTION}

Address of the author:

Christina Nikolova

莑”hrnikolova@unwe.bg
Transport energy efficiency is now very close to the top of the political agenda in many countries. There is a widespread consensus that progress towards sustainable development is essential. 
However, there is considerable debate as to what this term means? One particular part of this debate concerns the role of transport as a major consumer of energy and a generator of pollution. The question is: can transport activity be planned in such a way as to be more energy-efficient?

Demands for greater transport flexibility have increased dependence on road transport, which tends to raise aggregate energy consumption and generate air pollution and to have other adverse effects on the environment which, though not always cumulative and irreversible, are nevertheless not sustainable in the sense that they do not represent chosen outcomes. In practice, however, these adverse environmental (and social) impacts are very difficult to reverse once activity locations and personal lifestyles have been arranged to accommodate a high level of road transport dependency. The challenge is to devise management measures ensuring that the actual outcomes are chosen, rather than being the unintended and unforeseen consequences of the policies adopted.

Viewing transport within the general perspective of sustainable development yields some immediate insights on this process (Jeon \& Amekudzi, 2005). The weight placed on the various components of the general quality of life varies, of course, with the country and every country must ultimately define its own path of development. Whatever the preferred balance, increasing economic sustainability can always advance environmentally sustainable development, but does not necessarily do so. Failing to incorporate energy efficiency considerations in the assessment of projects and policies is what creates the "sustainability gap." The policy challenge is to recognize the trade-offs and to devise instruments that will prevent the sustainability gap from developing.

\section{ENERGY EFFICIENCY IN THE CONTEXT OF SUSTAINABLE TRANSPORT DEVELOPMENT}

Sustainability requires policy and institutional reform. The challenge is to define the strategy for enhancing energy efficiency that governments need to adopt in order to increase sustainability of transport. Generally, it is recognized that the problems are very diverse. Infrastructure and basic accessibility deficiency tends to be a more dominant problem, while service quality deficiency tends to be in the background. The policy and institutional changes that are necessary to enhance economic, environmental and social sustainability should be considered. The new focus does not vitiate the continuing importance of efficient transport to trade, mobility and, hence, to economic growth, or its contribution to the achievement of environmental and social objectives. However, it does highlight the fact that the traditional emphasis on public sector operation and regulation has often failed to make that contribution in a continuing, sustainable way. This has been partly a human resource problem, as governments do not possess adequate skills for carrying out the planning and control tasks required, and partly an institutional problem so far as governments continue to rely on mechanisms that make unrealistic demands on human resources and motivations. Therefore, we consider the new demands that the emphasis on sustainability place on governments.

\subsection{Energy efficiency as a headline indicator for sustainable transport development: analysis and assessment}

Final energy consumption covers all forms of energy, as they are delivered to the final consumers (industry, transport, households and other sectors), for all energy uses.

The data on figure 1 show the quantities of fuel consumed in the EU, expressed in tons of oil equivalent (toe). The final energy consumption of the EU-27 transport sector amounted to 351.1 million toe in 2012. It made up somewhat around one third $(31.8 \%)$ of total final energy consumption (Figure 2), a share which rose from 26.3\% in 1990.

This is due to transport's energy consumption growing at an average annual rate of $2 \%$ from 1990 to 2011, while energy consumption in industry was reduced (figure 3 ). 
Nikolova C. Management strategies for transportation system MEST Journal Vol. 2 No. 2 pp. 159-172

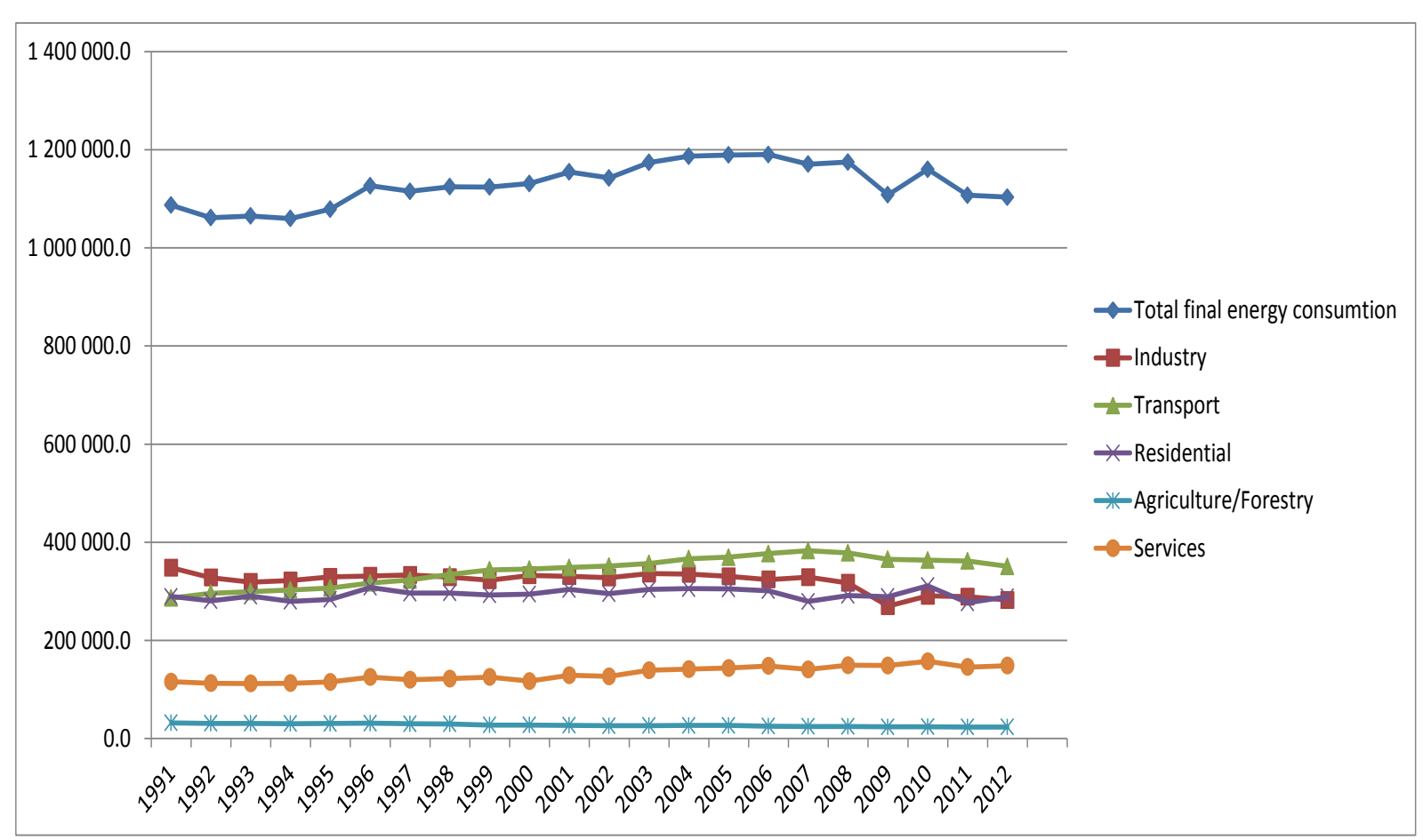

Fig. 1 Final energy consumption in EU, by sector (mtoe)

Source: (EUROSTAT, 2014)

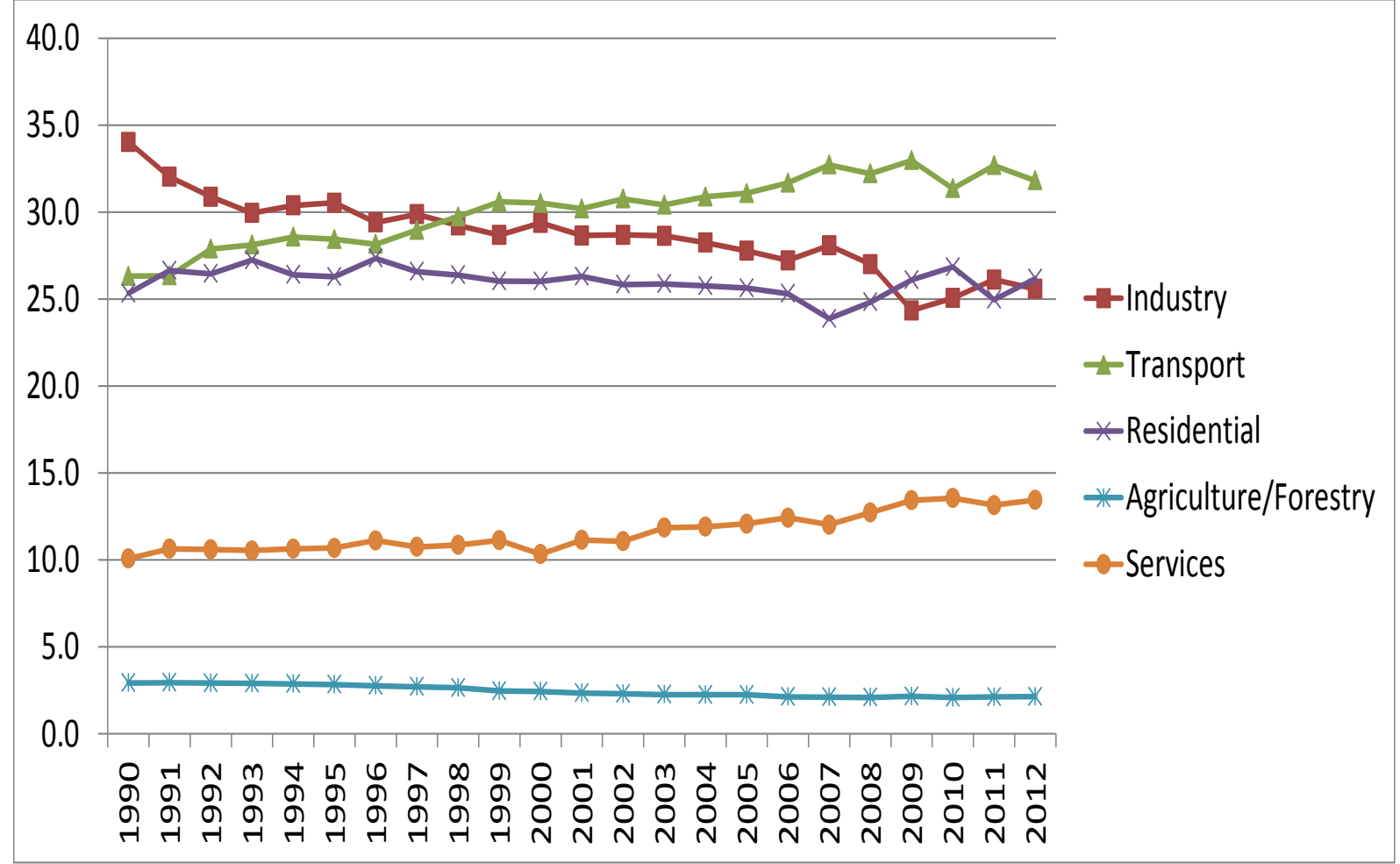

Fig. 2 Share in the final energy consumption by sector, 2012

Source: (EUROSTAT, 2013) 
Nikolova C. Management strategies for transportation system MEST Journal Vol. 2 No. 2 pp. 159-172

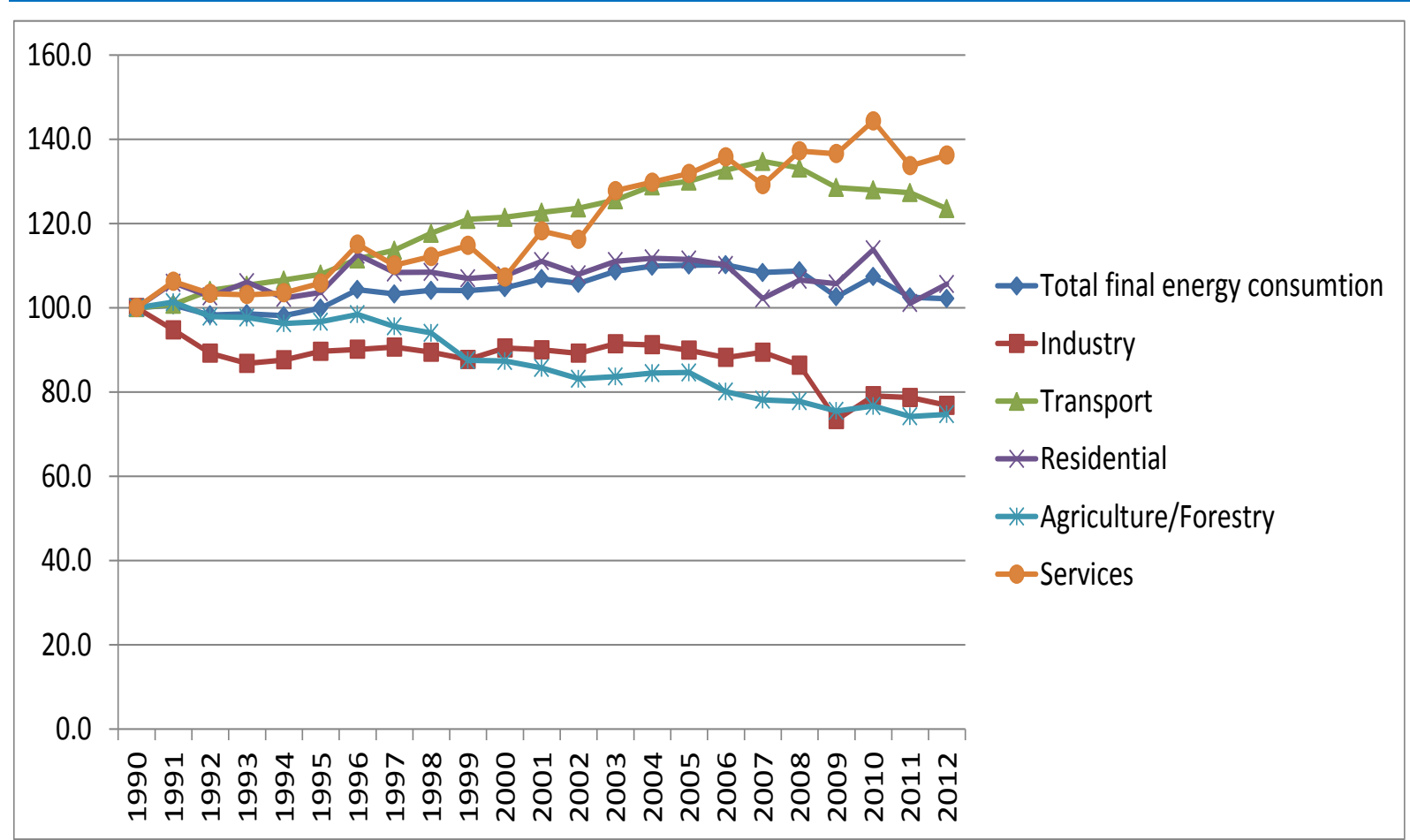

Figure 3 Change in the final energy consumption by sector, 2012

Source: (EUROSTAT, 2013)

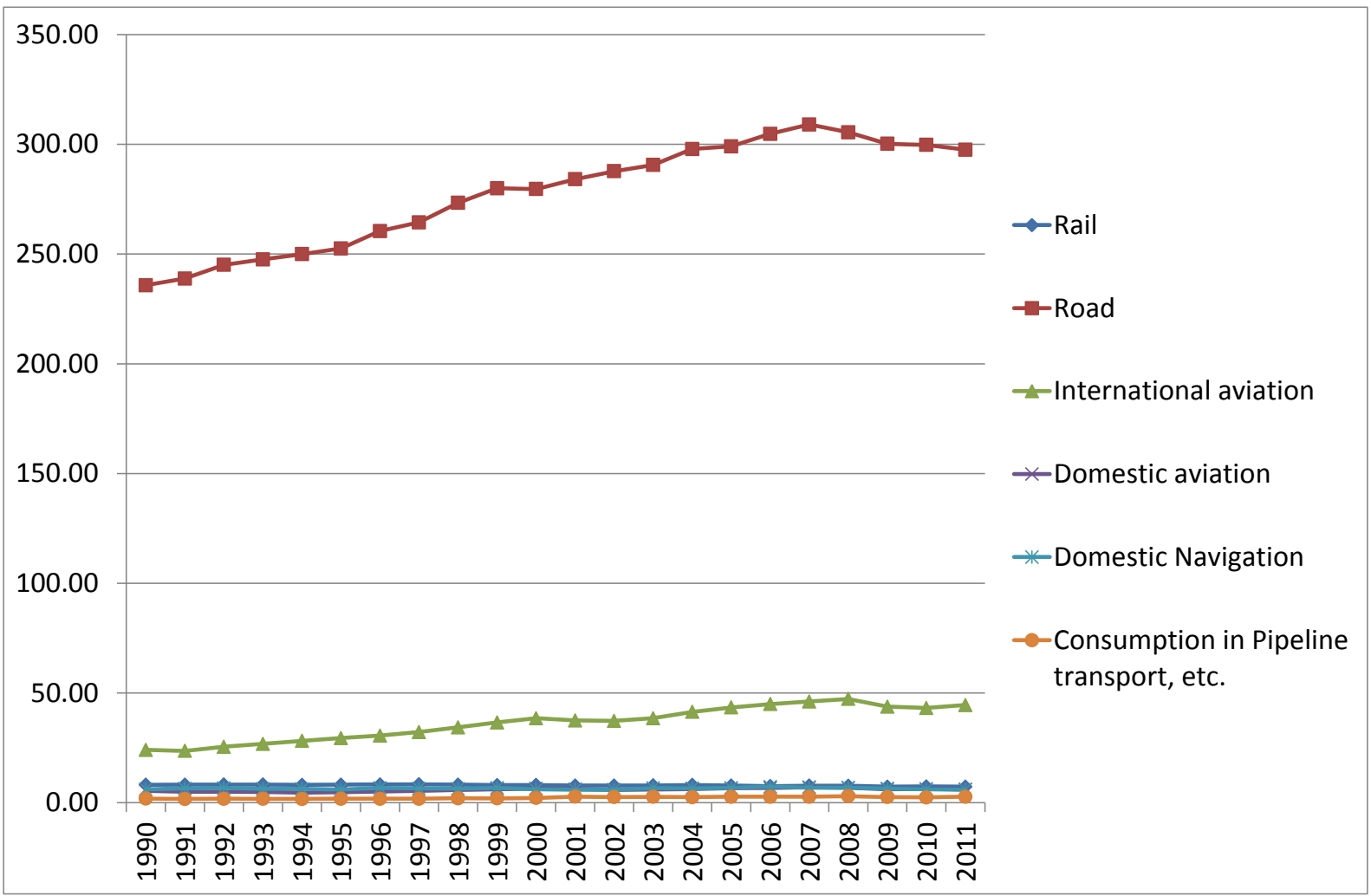

Figure 4 Final energy consumption by mode of transport

Source: (EUROSTAT, 2013) 


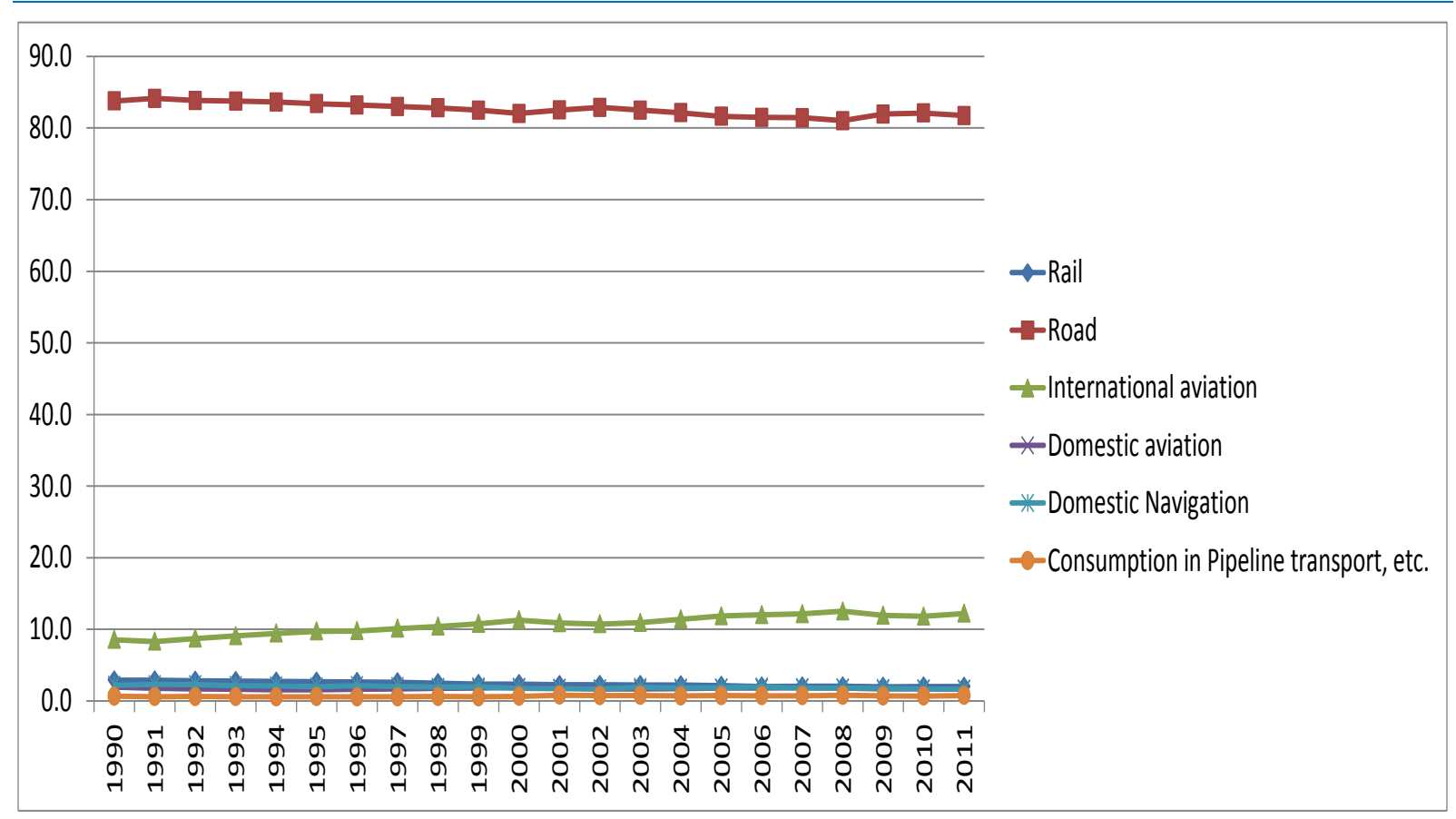

Figure 5 Share in final energy consumtion by modes of transport

Source: (EUROSTAT, 2013)

Transport accounted for $83 \%$ of the 108.6 million toe increase in total final energy consumption from 1990 to 2011. Growing fleets of passenger and goods road vehicles with higher performances, and a strong increase in the provision of air transport services in the reviewed period were the main contributors to the higher energy consumption of the transport sector. Road transport is the mode consuming most energy in the EU (figure 4).

From 1990 to 2011, the final energy consumption of road transport grew at an annual rate of $1.1 \%$, to reach 297.5 from total 364.08 million toe in 2011 , which amounted to $27 \%$ of total final energy consumption, and to $81.7 \%$ of consumption in transport (figure 5).

According to data from a recent EUROSTAT publication, private cars accounted for $56 \%$ and lorries for $40 \%$ of total energy consumption in road transport. Road freight transport also saw progress as it consumed 67 toe per million tkm.

Rail made up $2 \%$ of final energy consumption in transport in 2011 compared to $3.4 \%$ in 1990 . While energy consumption by rail was close to unchanged in 2004 compared to 1990, (both years: 9.6 million toe), it fell thereafter to reach 7.3 million toe in 2011. This is due to reductions in rolling stock. Given $1 \%$ yearly increases in rail passenger and freight transport performance over the period, energy efficiency gains may be expected to have been made, with for example electric-power replacing diesel oil.

Inland navigation was the transport mode that consumed least energy in 2011 (5,9 million toe) when it made up $1.6 \%$ of total transport energy consumption. From 1990 to 2011, energy consumption by inland navigation fell at an average yearly rate of $0.001 \%$. While vessel numbers have decreased, their performance has tended to grow, also pointing at energy efficiency gains.

The final energy consumption of air transport increased throughout the period, except between 2000 and 2002. It raised from 29.1 million toe in 1990 to 50.5 million toe in 2011, at an average annual rate of $3.0 \%$, the highest rate among the four transport modes covered. The share of air transport in final energy consumption increased from $10.4 \%$ in 1990 to $13.9 \%$ in 2011 . Through the improved design of aircrafts and engines, and through higher passenger and freight loads, air transport may be expected to have made noticeable energy efficiency gains measured in toe per pkm. 
Based on the analysis, the headline indicator for sustainable development of transport is set to be energy consumption relative to GDP. This indicator is defined as the ratio between energy consumption of transport and GDP (chain-linked volumes, at 2000 exchange rates). The energy consumed by all types of transport (road, rail, inland navigation and aviation) is covered, including commercial, individual and public transport, with the exception of maritime and pipeline transport.

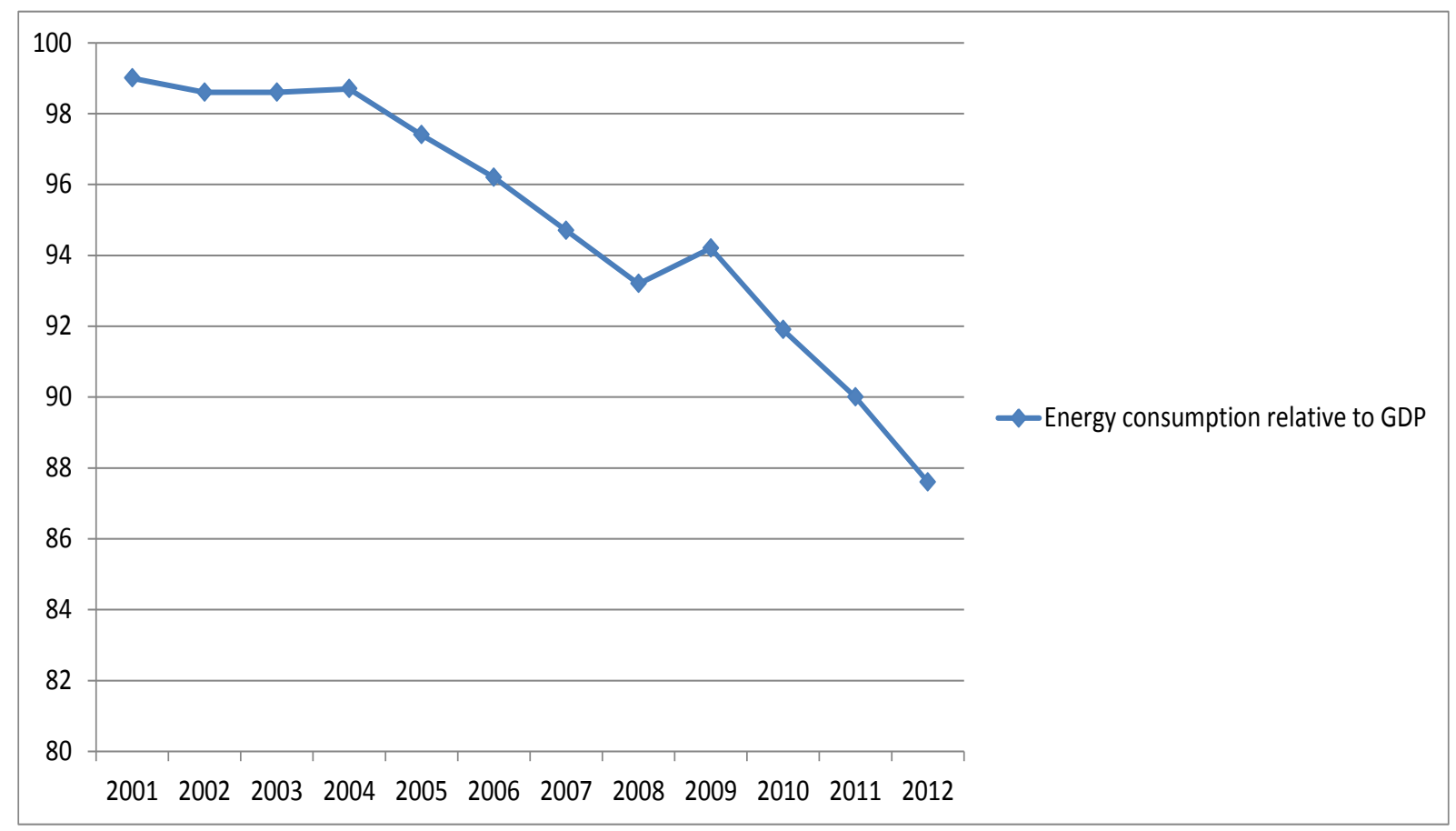

Figure 6 Energy consumption of transport relative to GDP

Source: (EUROSTAT, 2014)

Between 2000 and 2012, the energy consumption of transport in the EU increased by $8 \%$, whereas GDP grew at the somewhat faster rate of $12 \%$. As a result, the energy consumption of transport per unit of GDP decreased by an average of $0.6 \%$ per year, indicating a small relative decoupling.

The reduction in energy consumption in last years is evidently a consequence of the economic crisis and corresponding slowdown in economic activity as reflected in GDP. Even if 2010 has seen a small upturn in GDP, short-term data on sales of transport fuels indicate that consumption of energy by transport continued to fall in 2012 .

In the coming decades, oil and other fossil fuels are expected to become more expensive as demand increases and low-cost sources dry up. The negative impact on the environment will be greater, as conventional sources are replaced by more polluting supplies. At the same time, the need to move to a low-carbon economy and the growing concerns about energy security will bring about a greater supply of renewable energy, made much cheaper by technological progress and mass production.

Nearly the entire energy consumption of the EU transport sector consists of hydrocarbon fuels. In yielding their performance, transport vehicles combust fossil fuels and release substantial amounts of carbon dioxide $\left(\mathrm{CO}_{2}\right)$ as well as a range of other types of emissions harmful to human health and which can effect anthropogenic changes on the living environment.

As it could be seen from the figure 7, compared with 1990 levels, in no other sector has the growth rate of greenhouse gas (GHG) emissions been as high as in transport. This section predominantly covers the emissions of greenhouse gases which can contribute to global warming, and thus form a major external cost of transport. 
Nikolova C. Management strategies for transportation system MEST Journal Vol. 2 No. 2 pp. 159-172

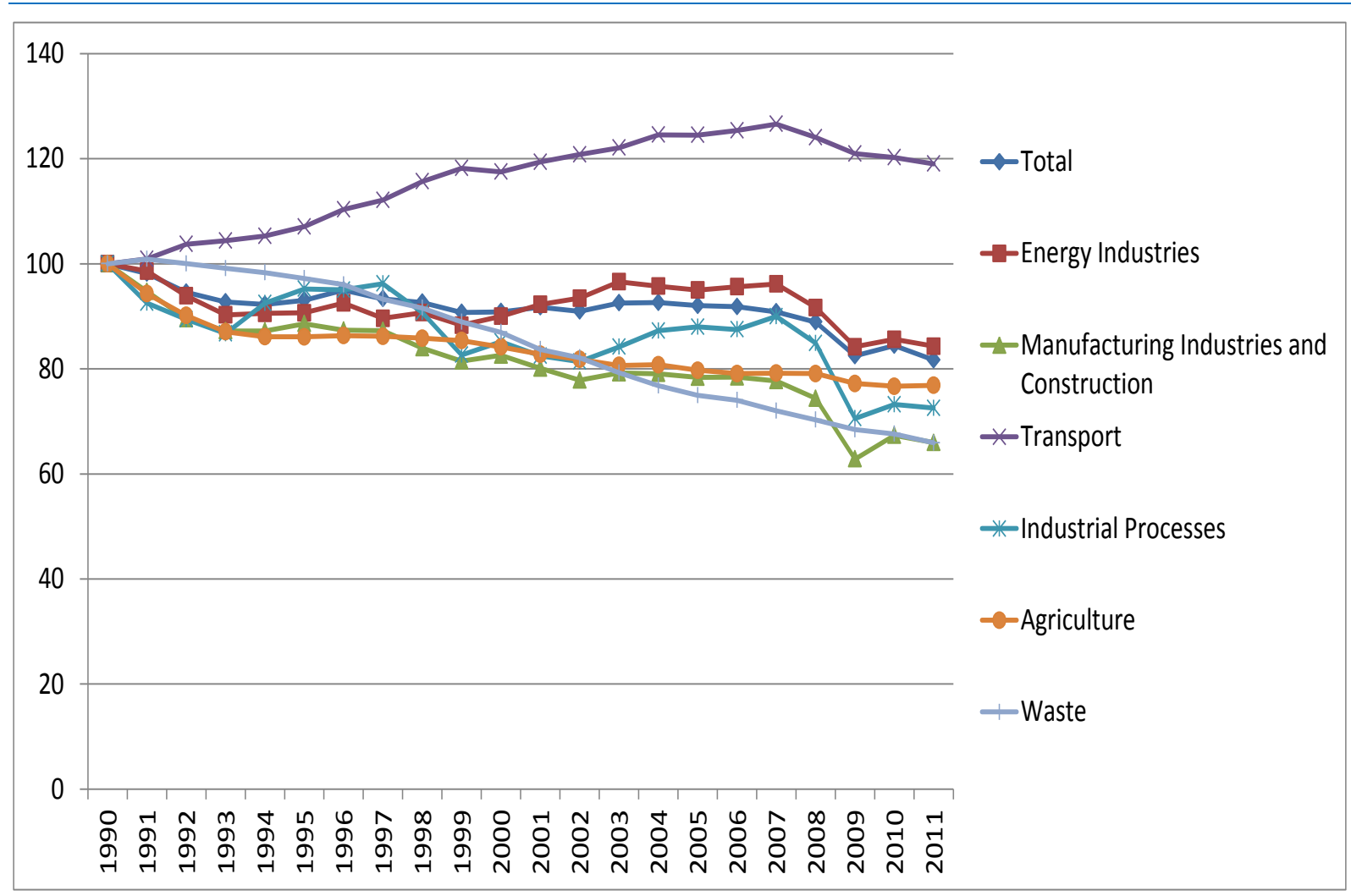

Figure 7 Change in GHG emissions by sectors, EU

Source: (EUROSTAT, 2013)

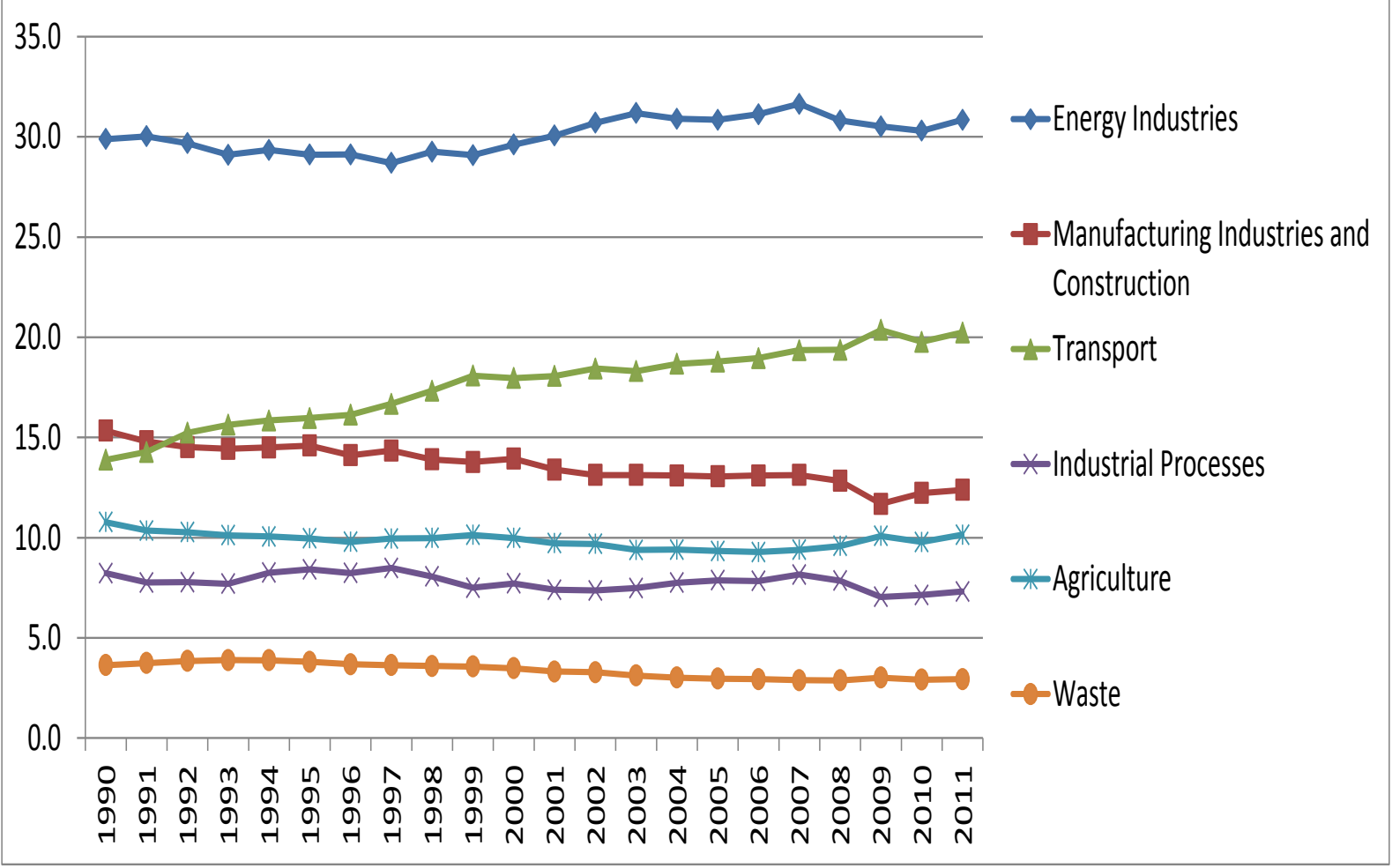

Figure 8 GHG emissions shares by sector in EU

Source: (EUROSTAT, 2013) 
Total GHG emissions of 926,4 $\mathrm{CO}_{2}$ equivalent were attributable to transport in the EU in 2011. Second largest after the energy industries $(30.8 \%)$, transport made up a share of $20,4 \%$ of total GHG emissions (Figure 8). Its proportional contribution has risen from 14\% in 1990 due to own-increases and to reductions in all other sectors. If one were to add the emissions of international maritime shipping and aviation calculated on the basis of emissions from bunkers - of which maritime shipping accounted for $57 \%$ and aviation for $43 \%$ - the total amount would rise from 961.8 to $1,297.3$ million tonnes $\mathrm{CO}_{2}$ equivalent.

In comparison to an average yearly decrease in total GHG emissions of $0.9 \%$ in the EU from 1990 to 2011 , transport was the only sector not to display a reduction in emissions, rather recording growth at an average annual rate of $0.8 \%$ over the period. This average yearly increase in total GHG emissions by transport was driven by annual increases of $1.4 \%$ in road transport and of $3 \%$ in air transport. In contrast, rail's GHG emissions fell at a yearly rate of $3.1 \%$ over the period (see figure 9 ).

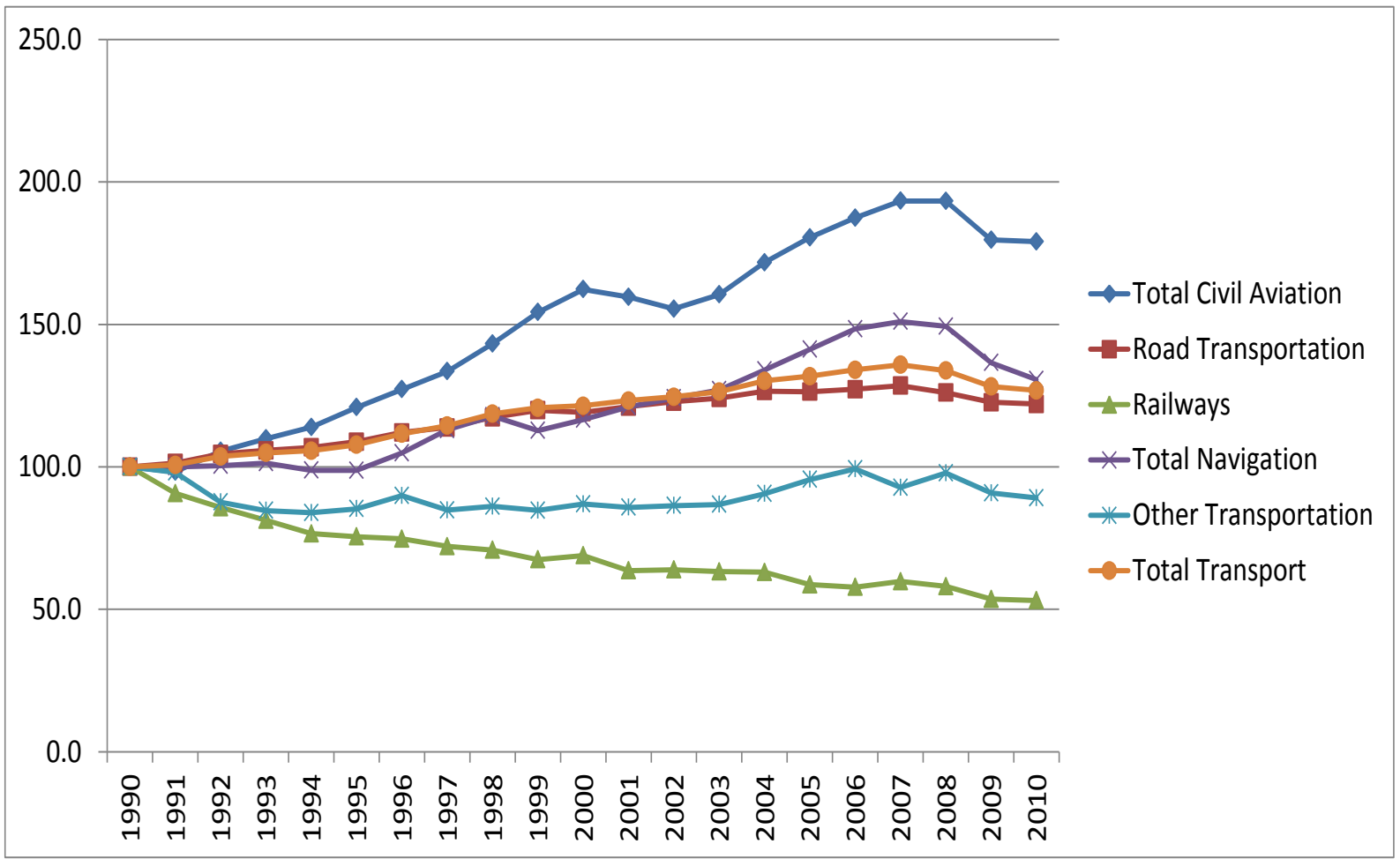

Figure 9 Change in GHG emissions from transport by mode, EU

Source: (EUROSTAT, 2013)

Road transport contributed $72.1 \%$ to the greenhouse gas emissions of the transport sector in 2011 (Figure 10). Its share in total transport emissions rose from around $74.9 \%$ at the beginning of the first half, then stabilizing at above $75.8 \%$ in 1994 . This may be attributed to the road sector's growth and to the reduced emissions of other transport modes. After peaking in 1994, road's contribution to the total GHG emissions of transport fell gradually due to the growing share of air transport (from $8.8 \%$ in 1990 to 12.5 in 2011).
With the aim of improving air quality, cars have to comply with standards for exhaust emissions before being sold on the EU market. Successive 'Euro' emission standards for passenger cars and light vehicles - typically referred to as Euro I, Euro II, etc. - have already helped to reduce air pollution from cars, for example by obliging carmakers to equip exhaust pipes with catalytic converters and particle filters (EUROSTAT, 2009).

The Euro standards set limits on vehicles' emissions of carbon monoxide (CO), hydrocarbons $(\mathrm{HC})$, oxides of nitrogen $\left(\mathrm{NO}_{\mathrm{x}}\right)$ and 
particulate matter (PM). Separate emissions regulations apply for diesel and petrol cars, vehicles of successive motor capacity, heavy-duty lorries and buses as well as motorcycles. New cars' and light commercial vehicles' (vans) emissions are currently regulated by the Euro $\mathrm{V}$ standards which came into force in 2009. Reducing emissions from road vehicles has come a long way, and the proportion of cars complying with the latest and most stringent emission standards is increasing.

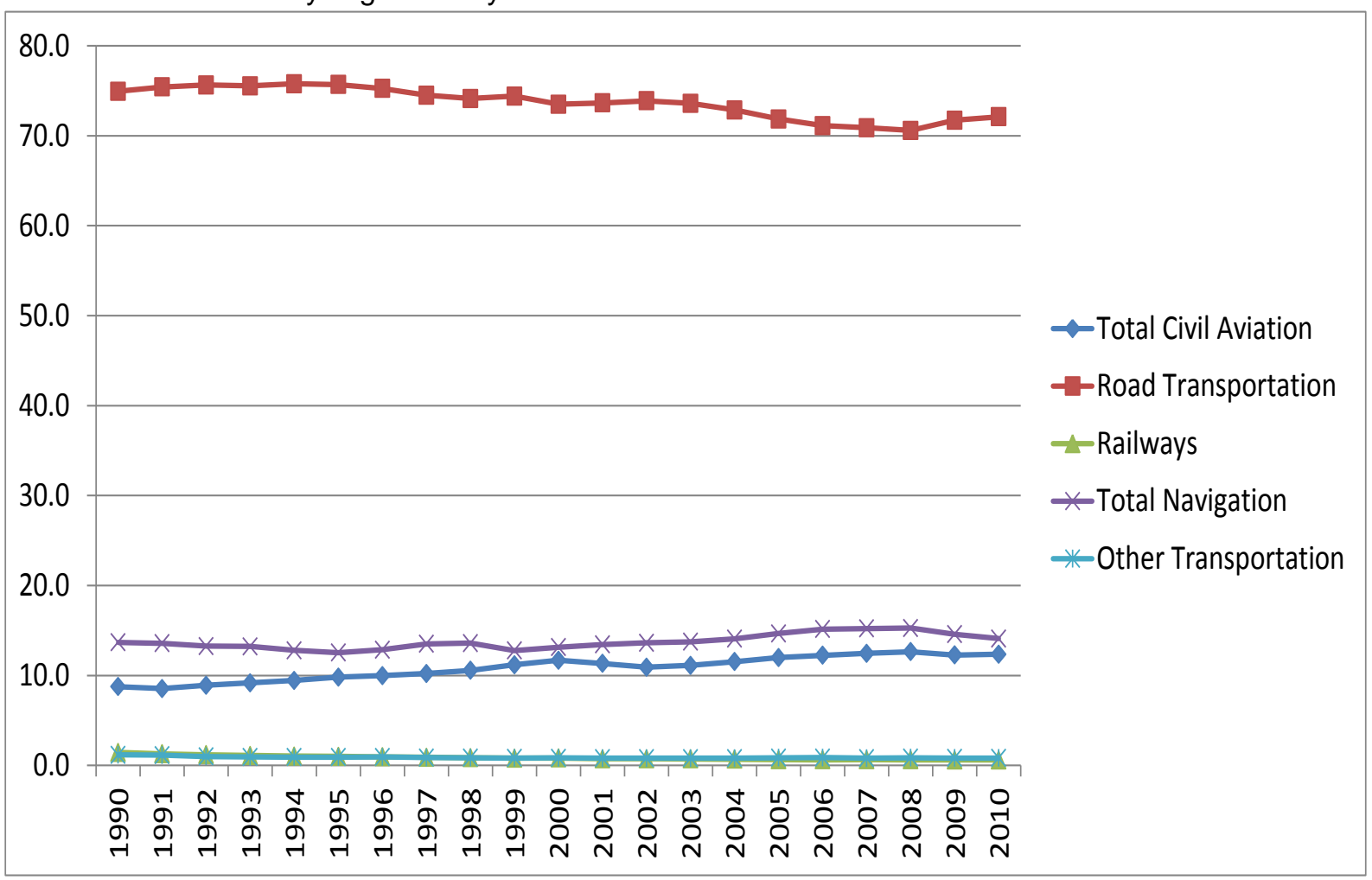

Figure 10 Share by mode in total transport GHG emissions, EU

With a share of $2.3 \%$ of transport greenhouse gas emissions, and displaying an average annual growth rate of $0.8 \%$ from 1990 to 2011 , inland navigation is of considerable interest from the perspective of greenhouse gases and it still has potential for further development at EU level.

According to EUROSTAT external trade data, maritime transport is used for about $70 \%$ of the EU's freight exchanges with the rest of the world. International navigation accounted for $13 \%$ of EU transport sector GHG emissions in 2011. In November 2002, the European Commission adopted an European Union Strategy to reduce atmospheric emissions from seagoing ships. The strategy reports on the magnitude and impact of ship emissions in the EU and sets out a number of actions to reduce the contribution of shipping to acidification, ground-level ozone, eutrophication, health, climate change and ozone depletion (DGTREN, 2009).

Liberalization of air traffic has certainly brought further positive effects with regard to the 'democratization' of air travel, but it is increasing rapidly, at rates which may outperform the impact of technological improvements that reduce engine emissions. At a local level, in the immediate vicinity of airports, concerns focus on the potential health and environmental effects of noise and air pollution, especially from NOx, volatile organic compounds and particulates.

Not only was air transport the fastest growing energy consumer in the EU transport from 1990 to 2011, but it was also the fastest climbing contributor of GHG as its emissions grew at an average annual rate of $3 \%$. 


\subsection{Measures for improving energy efficiency of transport}

The growth of transport activity raises concerns for its environmental sustainability. Transport systems are major emitters of greenhouse gases. Currently $95 \%$ of transport energy comes from petroleum, although electric trams and trains are also common and natural gas is used as well. Internationally, biofuels are forecast to have little or no impact on greenhouse emissions, at significantly higher cost than energy efficiency measures (Munasinghe, 1993). Electric vehicles are another technology which has the potential to reduce transport $\mathrm{CO}_{2}$ emissions, depending on the embodied energy of the vehicle and the source of the electricity.

On the other hand, the environmental impacts of transport can be reduced by improving the walking and cycling environment in cities, and by enhancing the role of public transport, especially electric rail. The most popular forms of green transport, providing a way of sustainable mobility are walking, bicycling and so-called green vehicles. Green vehicles also include:

- Solar vehicles - not practical day-to-day transportation devices at present, but are primarily demonstration vehicles and engineering exercises, often sponsored by government agencies;

- Wind-powered electric vehicles;

- Electric cars - currently, in most cases, electrical power is derived from battery packs carried on board the vehicle;

- Hybrid vehicles; and

- Electric trains and electric buses.

As the transport sector relies on fossil fuels for $97 \%$ of its needs, the fight against climate change in this sector goes hand in hand with efforts to improve its energy efficiency. Over recent decades, EU transport has increased at a sustained pace. Freight transport generally follows trade activity and has grown more than GDP, while passenger transport, except for aviation, has undergone a less dramatic rise (see figure 11) . These trends can only be sustained, however, if transport radically improves its energy efficiency and reduces its GHG emissions.

Apart from the choice of vehicle and transport mode, a key to further reducing energy consumption and pollutant emissions is the efficient use.

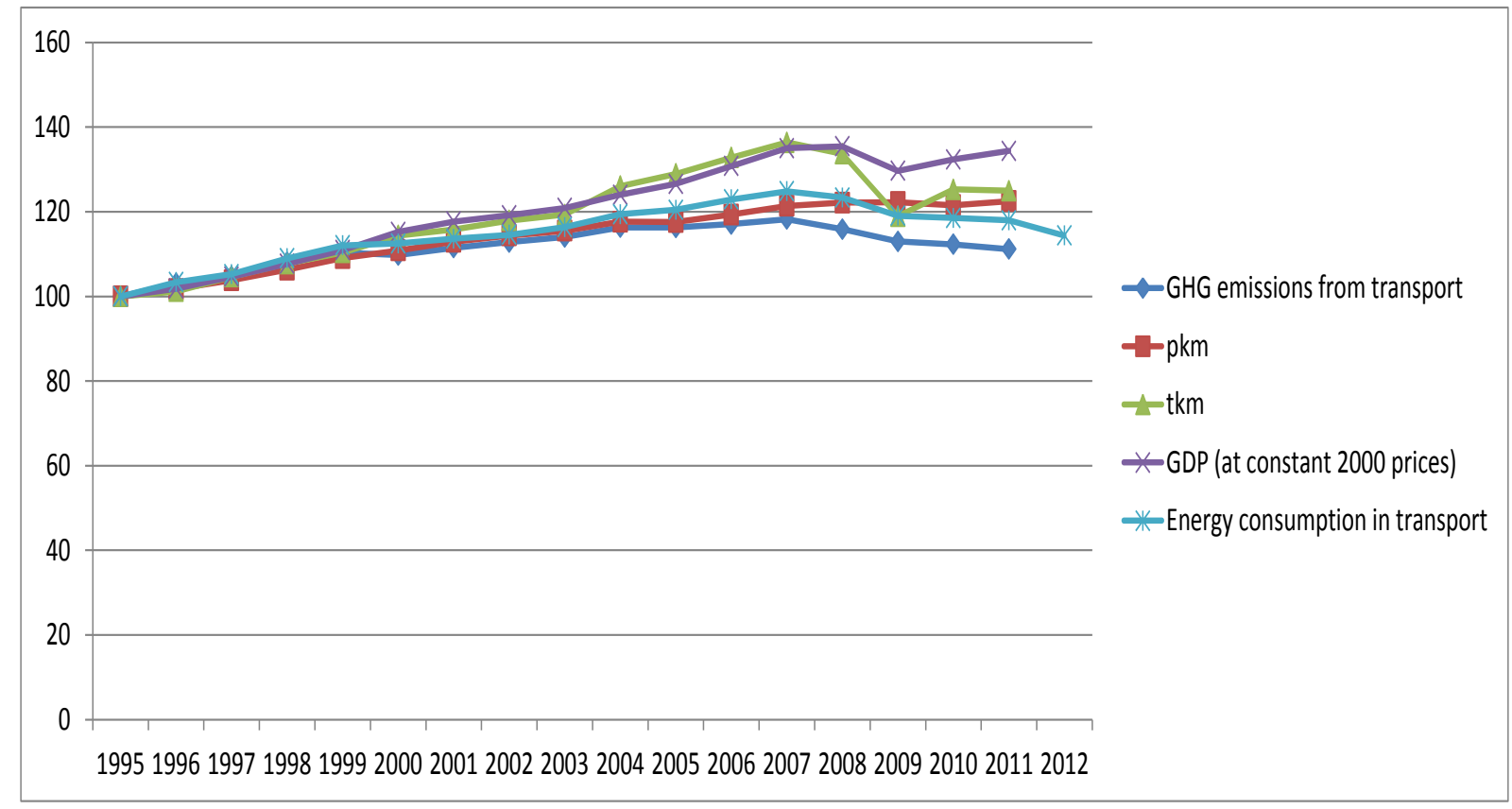

Figure 11 Change in energy consumtion and GNG emissions relative to GDP, freight and passenger traffic, EU Source: (DG MOVE, 2013) 
The more efficiently vehicles are used - through their higher occupancy rate, optimum volumes of goods transported, style of driving, etc. - the less energy is consumed and the less pollution is caused per person or per tonne of goods per kilometre travelled. Occupancy rates have generally tended to decline over time both for passenger cars and for buses and coaches, while they have remained more or less constant for rail transport. In contrast in air transport, a steady increase in the occupancy rate has taken place. This can be explained, for example, by the increased demand in air travel, the further development of hub-and-spoke systems and the market penetration of low-cost carriers (Gudmundsson, 2004).

Obviously, there is a compelling need for a technological shift towards lower and zeroemission vehicles and for the development of alternative solutions for sustainable transport. The $21^{\text {st }}$ century will most likely see the replacement of vehicles relying on the internal combustion engine by electric vehicles, including fuel-cell vehicles. At present, electric and fuel-cell cars remain expensive for their performance. While research is closing the cost-competitiveness gap, improvements can be made to the internal combustion engine where the fossil fuels they use can be complemented with biofuels.

The European 'green cars' initiative focuses on five main areas of research:

- electric and hybrid vehicles,

- hydrogen fuel cells,

- biofuels,

- improvements in the internal combustion engine and

- logistics.

Funds provided under this initiative come from two main sources: grants from the EU's seventh research framework programme (EUR 1 billion) and loans from the European Investment Bank (EUR 4 billion).

In addition, the fuel cells and hydrogen joint technology initiative brings together resources from the EU and the private sector to accelerate the development and broad market introduction of these two technologies (ERTRAC, 2007).

The development of modern aircraft, road vehicles, rail and maritime fleets and new logistic concepts linked with the renewal of fleets can be considered the major determinants of increasing energy efficiency. However, external incentives determined by markets and policies - strongly affect the time taken for fleet renewal and modern logistics concepts to take root.

Another crucial problem related to the negative effects from transport is the noise. Noise created by transport has been attracting increasing attention in recent years, and has lead to various measures at EU level concerning the harmonization of noise assessment and management, market access requirements for certain vehicles and equipment, railway interoperability specifications and rules on operating restrictions at airports.

Measures taken in road transport include the more widespread use of 'quieter' car tires with low rolling resistance (for increased fuel efficiency) and the use of noise-absorbing road surfacing as well as mitigation measures such as the construction of noise barriers along roads through or near residential areas.

Railway industry measures cover infrastructure operators (e.g. the acoustic grinding of rails, noise barriers, speed limits at night) and train operators (e.g. replacement of cast-iron brakes with lownoise composite materials). Newly constructed high-speed train tracks are mostly built with noise barriers along sensitive areas.

Aircraft are particularly noisy and they largely affect areas at and around airports, even if modern aircraft are 10 to 15 decibels quieter than previous generations of aircraft. Current legislation provides for the reduction of airplanes' noise at source, land-use planning and management measures, noise abatement operational procedures and operating restrictions. Another area offering potential for reducing aviation's environmental impact is the improvement of air traffic management. 
Many Europeans still remain exposed to dangerously high levels of air and noise pollution. Transport itself is suffering from the effects of climate change and necessitating adaptation measures. Global warming resulting in a rising sea level will amplify the vulnerability of coastal infrastructures, including ports. Extreme weather events affect the safety of all modes. Droughts and floods pose problems for inland waterways.

Transport activities give rise to environmental impacts, accidents and congestion. In contrast to the benefits, the costs of these effects of transport are generally not borne by the transport users. The internalization of external costs means making such effects part of the decision-making process of transport users. Besides, the measures for improving the use of existing infrastructure are related to shift towards more ecological modes of transport. It could be achieved through internalization of the external costs for transport. With regard to this the infrastructure charges could be considered as economic instruments for decreasing oil consumption and pollution.

The European Commission released in 2008 a handbook with estimates of external costs in the transport sector (Maibach, et al., 2008). The handbook, jointly prepared by several transport research institutes, summarizes the state of the art as regards the valuation of external costs. The Commission intends has make use of this handbook to prepare a communication on a strategy to internalize the external costs for all modes of transport.

Expected results from the initiative are related to:

- the opportunity for balancing modal split while considering for externalities, which will lead to more efficient impact of charges on the use of the infrastructure;

- more efficient use of the transport infrastructure - will lead to reduction in budget expenses for infrastructure, healthcare and environment as well as to direct financial benefits for lower taxes.

The net effect in commercial sector is expected to be positive and direct effect from higher infrastructure charges to be neutralized by decreasing costs for congestions, accidents and by all possible reductions in taxes given by the governments.

\section{MANAGEMENT STRATEGIES FOR ACHIEVING THE STRATEGIC GOALS FOR ENERGY EFFICIENCY}

Most transport improvements are designed to reduce transport costs. This can often have a beneficial impact on the environment, for example, by reducing fuel consumption and air pollution. Almost all transport projects are subject to at least a partial assessment. The increasingly stringent application of these procedures has encouraged the design of projects that are sensitive to energy efficiency concerns and that mitigate any directly adverse environmental impact. Furthermore, transport projects, or project components, are increasingly going beyond avoiding direct harm and focusing more positively on environmental improvements. These projects address the immediate and direct effects of transport. In such cases the fundamental question is what should be the main accent in transport policy and management?

Mamagement strategies in transport are, in principle, based on a full cost-benefit analysis incorporating both transport and environmental objectives (World Bank, 2008). They include short-term management and pricing instruments and long-term strategic instruments as the context for identifying investment actions. Still, further research will be required to identify critical environmental effects and to determine the efficacy of different interventions. In the interim, an appropriate framework for achieving energy efficient and environmentally friendly development of transport would include:

- Strategic and structural actions, including the creation of economic incentives for sensitive behavior regarding energy efficiency, would be of a high priority. Although their effects may be slow to come to fruition and may be politically and administratively difficult to be implemented, they are the critical and pervasive basis for sustainable transport development. Within that strategic framework, some priority problems can be identified where the benefits of making improvements 
are judged to be very high, particularly because they are seriously life- and healththreatening.

- The most appropriate technology should be selected on the basis of relative energy efficiency, in the context of the main problems in transport, taking into account what the companies can afford and effectively implement. This often means that the actions with the highest priority are not those attempting to impose "state-of-the-art" standards or technologies but those that make more immediate, implementable changes in the way in which existing equipment is used.

Transport system that falls into disrepair because it is economically unsustainable fails to serve the needs of the clients and often have environmentally damaging consequences. Hence, there are some management instruments which serve all of the dimensions of sustainability in a synergic way, generating "win-win" solutions. These include measures aiming to improve asset maintenance, charging for external effects, technical efficiency of supply, safety, contract design, and administration. Increased mobility in the EU counties, particularly private motorized mobility, typically increases measured GDP but damages the environment.

\section{CONCLUSIONS}

There is growing urgency for the transport sector to mitigate its negative impact on the environment.
The respond to the goals of the EU Sustainable Development Strategy and the aim to reduce transport's environmental impacts involve progress towards a number of environmental policy objectives. Lowering consumption of nonrenewable resources is essential for all aspects of transport systems and their use. The undesired environmental consequences of transport activity will require further action in particular on noise, air pollutant emissions and greenhouse gas emissions. EU legislation sets requirements in many of these areas but these will require assessment and updating in the future.

Besides, policy-makers are facing demands to meet the changing mobility needs of citizens in ways which are economically, socially and environmentally sustainable. Cities need efficient transport systems to support their economy and the welfare of their inhabitants. Around $85 \%$ of the EU's GDP is generated in cities. Urban areas face today the challenge of making transport sustainable in environmental $\left(\mathrm{CO}_{2}\right.$, air pollution, noise) and competitiveness (energy efficient) terms while at the same time addressing social concerns. These range from the need to respond to health problems and demographic trends, fostering economic and social cohesion to taking into account the needs of persons with reduced mobility, families and children (DG-TREN, 2009).

\section{WORKS CITED}

DG-TREN. (2009). A Sustainable Future for Transport. Retrieved from European Commission: http://ec.europa.eu/transport/publications/doc/2009_future_of_transport_en.pdf

ERTRAC. (2007). The competitive route to sustainability and safety. Retrieved from European Road Transport Research Advisory Council (ERTRAC): http://ec.europa.eu/research/transport/transport_modes/road_en.cfm

EUROSTAT. (2009). Panorama of transport. Retrieved from Eurostat http://epp.eurostat.ec.europa.eu/cache/ITY_OFFPUB/KS-DA-09-001/EN/KS-DA-09-001EN.PDF, doi:10.2785/28475

EUROSTAT. (2013). Energy statistics (Eurostat) . Retrieved from European Environment Agency: http://www.eea.europa.eu/data-and-maps/data/external/energy-statistics-eurostat

EUROSTAT. (2014). Energy consumption of transport relative to GDP. Retrieved from European Commision eurostat: http://epp.eurostat.ec.europa.eu/tgm/table.do?tab=table\&init=1\&language $=$ en\&pcode $=\operatorname{tsdtr} 10$ 0\&plugin $=0$ 
Gudmundsson, H. (2004). Sustainable Transport and Performance Indicators. In R. Hester, \& E. al., Transport and the Environment (pp. 35-62). UK: Thomas Graham House.

Jeon, C., \& Amekudzi, A. (2005). Addressing Sustainability in Transportation. Journal of Infratsructure System, 11(1), 31-50.

Maibach, M., Schreyer, C., Sutler, D., van Essen, H., Boon, B., Smokers, R., . . Bak, M. (2008). Handbook on estimation of external costs in the transport sector. Delft: CE Delft.

Munasinghe, M. (1993). Environmental Economics and Sustainable Development. World Bank Environmental Paper Number 3.

World Bank. (2008). Sustainable Transport: Priorities for Policy Reform. Washington D.C. Retrieved from Roads and Highways Department: http://siteresources.worldbank.org/INTTRANSPORT/Resources/tp_15_urban.pdf

Received for publication: $\quad 29.01 .2014$

Revision received: $\quad 19.06 .2014$

Accepted for publication: $\quad 05.07 .2014$

How to cite this article?

Style - APA Sixth Edition

Nikolova, C. (2014, 07 15). Management strategies for achieving energy efficient and sustainable transportation system. (Z. Čekerevac, Ed.) MEST Journal, 2(2), 159-172. doi:10.12709/mest.02.02.02.17

\section{Style - Chicago Fifteenth Edition:}

Nikolova, Christina. 2014. "Management strategies for achieving energy efficient and sustainable transportation system." Edited by Zoran Čekerevac. MEST Journal (MESTE) 2 (2): 159-172. doi:10.12709/mest.02.02.02.17.

Style - GOST Name Sort:

Nikolova Christina Management strategies for achieving energy efficient and sustainable transportation system [Journal] // MEST Journal / ed. Čekerevac Zoran. - Belgrade : MESTE, 07 15, 2014. - 2 : Vol. 2. - pp. 159-172.

Style - Harvard Anglia:

Nikolova, C., 2014. Management strategies for achieving energy efficient and sustainable transportation system. MEST Journal, 15 07, 2(2), pp. 159-172.

Style - ISO 690 Numerical Reference:

Management strategies for achieving energy efficient and sustainable transportation system. Nikolova, Christina. [ed.] Zoran Čekerevac. 2, Belgrade : MESTE, 07 15, 2014, MEST Journal, Vol. 2, pp. 159172. 